\title{
Higher Vocational College Computer Education Dilemma and Solution Ways Exploration
}

\author{
Chunli Song \\ Lijiang Teachers College, Lijiang, 674100, China
}

Keywords: Higher vocational college. Computer education. Curriculum provision. Practical teaching

\begin{abstract}
With the advent of the information age, the growing economic and social development needs more and more computer professionals which creates a good employment opportunities for vocational computer professionals. However, due to the bias positioning of Chinese computer education vocational colleges, the teaching mode cannot meet the training requirements of high-quality talents, leading to low computer application skills in graduate students and they don't mastered advanced computer practical knowledge, thus higher vocational college computer education is facing with the grim situation of declining employment rate This article will explore the predicament and solution ways faced by higher vocational computer education.
\end{abstract}

\section{Higher Vocational College Computer Education Dilemma}

\section{Unreasonable computer education positioning}

Higher vocational computer education goals should be set for training computer application-oriented talents, to bridge the gap between engineers and operators. However, from the current educational situation, some higher vocational college just copy the computer training model from universities, there is no curriculum system build from their own educational characteristics, emphasis too much on theoretical study, ignore students' hands-on operational capabilities training, thereby constraining students' career development.

\section{Rigid teaching mode}

Most computer teachers' teaching mode still adopt force-feeding teaching mode which emphasize on theoretical knowledge only which make students in a passive state. The lack of effective interaction between teachers and students will make the classroom bold and boring, seriously weaken students' interest. Meanwhile, the teachers do not pay attention in updating teaching content, the theory teaching is far from the and practical teaching which is not good for students' improvement in computer application skills and unable to meet the higher vocational talents training requirements.

Practical teaching software and hardware construction lag

Most of Chinese higher vocational colleges in talent training plan, the school-running idea, the teachers, practice base, experiment equipment and other hardware and software aspects are still in constant reform and improvement phase, and the experiment and training environment is relatively backward. Part of the colleges' computer rooms' configuration stay at the levels of a few years ago, not spending enough money to build the new training room. This makes the practice teaching to adopt outdated versions software which leads to low levels of practice teaching.

\section{Lack of teachers}

The overall quality and ability of higher vocational computer teachers is low, mainly displays in: first, some teachers are part-time teachers, there is few full-time teachers. In teachers' structure, there is few teachers with a higher degree, at the same time, most of the teachers are lack of enterprise experience which lead to hard improvement for computer practical teaching quality. Second, teachers' knowledge level do not keep pace with the development of the information age, failed to timely grasp of advanced computer technology and application, combined with higher vocational college do not pay attention to computer teachers' training so as to make most of the teachers' knowledge aging phenomenon are widespread. 


\section{Ways to Solve Higher Vocational College Computer Education Dilemma}

\section{Optimize the curriculum system}

For higher vocational college computer professional course, each course is relatively independent and there is a certain contact between each other. Through the course system, these classes can be organically links as a whole which will make the computer education teaching work smoothly, also can make the formation of professional teaching plan with the characteristic of higher vocational education, promote vocational computer education get out of the dilemma they have now. In the higher vocational college computer course setting process, make students' career development as the basic goal, correctly handle various relations on the basis, such as the relationship between profession and vocation, education certificate and professional qualification certificate, etc. This helps to broaden the students' career development space, thus lay a solid foundation for students' lifelong career development. At the same time, in the process of building computer specialize curriculum system, take cultivating students' practical working ability as the core target and take basic knowledge learning as the prerequisite of the auxiliary core goal. In this view, professional curriculum system of higher vocational college computer settings should match with the students future working task, and mainly based on the specific application of computer, all the professional courses must be able to provide knowledge and skills needed for students to enter the professional which help students to quickly adapt to post requirement after work. In addition, take the project curriculum as the main body of the entire computer professional curriculum, and have a reasonable arrangement for specific curriculum according to the order from practice to theory, emphasis on the students' professional ability training to form targeted course content and integrate the corresponding knowledge and skills based on post work tasks as the premise and foundation to realize the unity of the basic theory and practice of the computer courses, to create a complete experience learning opportunities of working process for students, and to help their role transformation from the learner's to the post workers step by step, which helps to improve students' employment rate after graduation.

\section{Use effective teaching methods}

Higher vocational computer teaching should use various teaching methods flexibly and transfer single teaching method and boring teaching process, mobilize students' interest to participate in teaching activities so as to improve the quality of computer teaching.

\section{Case teaching method.}

The outstanding feature of this teaching method is able to effectively stimulate student's creation enthusiasm, helps to develop students' innovative ability. When use case teaching method in the computer classroom teaching, teachers can refine the curriculum content into case, and send to students in the form of a question, and then let the students carry out activities through group discussion in the classroom and get the final results. In this process, students need to consult a lot of useful information related to the case, the team members need to discuss with each other at the same time, thus to arouse the enthusiasm of the students' learning. It is not only to cultivate the students' ability to analyze and solve practical problems, but also further active classroom atmosphere. Practice has proved that reasonable use of this method in the computer teaching can help higher vocational computer education get rid of the current plight.

\section{Interactive teaching methods.}

This teaching method's effect in students' professional ability training of computer professional is very significant. Interactive teaching method can be applied in computer operate of classroom teaching, the method is to give full expression to the take the student as the main body of education concept. In the computer room, the teacher enables students to actively participate in teaching activities through interactive teaching methods, so as to change passive learning into active learning. At the same time, students are able to master professional knowledge and skills in the process of the students in their practical operation which helps improve the computer teaching efficiency and quality.

\section{Task type teaching method}


This teaching method can cultivate students' independent thinking ability and self-innovation consciousness which promote students' self-improvement and development. Task type teaching refers to divide classroom teaching into several work units, and let the students in the form of team to complete the task. In computer practice teaching, teachers' teaching target can be implied in various work units, to make students understand the knowledge at the time of complete the task. When use this method in computer teaching, teachers should build a real teaching environment for students. Let student take the mission to study in such an environment. With the completion of each task, students can grasp the corresponding knowledge and skills. It is important to note that to the difficulty of the task should be moderate, if a task can't be completed, it will affect the students' study enthusiasm.

\section{Hierarchical teaching method}

Hierarchical teaching method can meet the requirements of different students' computer learning; make students with uneven foundations gain mutual learning progress. In computer teaching, the teacher can divide students into three learning grade(excellent, general and poor level) according to the situation of students' basic computer to break up the traditional class teaching mode boundaries, give students' several teaching according to different levels of students learning. For top level students, teacher wants to increase the teaching difficulty, not only to make students master the basic operation skills, but also to enable students to learn various software operation as the key; for the average level students, teachers should make students constantly consolidate the knowledge, increase the teaching difficulty appropriately and steadily improve the students' computer application ability; for poor students, teachers should begin from the basic computer teaching, and make students grasp basic computer knowledge, and then solid and rich teaching contents to make students have a good learning phase transition.

\section{Emphasis on practice teaching reform}

Practice teaching is an essential link of computer teaching; it is an important way to cultivate students' operation ability, comprehensive knowledge application ability, solve actual problem ability. Practice teaching is the key of the higher vocational education, highlight the characteristics of higher vocational education through strengthen the practice teaching reform to realize the talents training goal of higher vocational college. Computer education should begin from the following aspects, to improve the practice teaching effect:

\section{Emphasis on practice teaching base construction}

Computer practice teaching bases are including on and off campus base construction. In the construction of the campus base, establish training room should make full use of various resources and make the training rooms with cutting-edge technology in the IT field, such as enke network technology training rooms, huawei network technology training rooms, e-commerce training rooms, ORACLE technology training room, computer application basis training rooms, game design training rooms, software testing laboratories, mobile application development training rooms, computer assembly and maintenance training rooms, etc., to ensure the construction of training rooms can meet the needs of the practice teaching of the course in computer education. In the construction of off campus base construction, make enterprises accept students' practice and internship though establish long-term close relationship with the enterprise. Develop the enterprises which have a certain size and strength enterprises as the off-campus practice bases to create good conditions for outstanding graduates to stay in business. In addition, higher vocational colleges must keep innovating the mode of cooperation in running schools with enterprises, to make students learn the enterprise business philosophy and management culture in practice outside, strengthen students' adapt ability and help students to enter society practice stage earlier.

\section{Optimize practice teaching content}

Computer practice teaching should embody the characteristics of occupation, advancement, comprehension. Among them, the occupation requires computer training content should meet the practical application needs of the enterprise to help students accumulate professional experience engaged in the work and cultivate the students' professional quality. Advancement refers to the computer practical teaching content must be involved in the latest technology and conform to the development trend of current technology trends. Higher vocational computer education should 
appropriately delete outdated practice content every year; actively introduce new products and new technology. Comprehension refers to the increase comprehensive training project in the practice teaching; make the project involve multiple curriculum knowledge to cultivate students' analysis and problem solving skills in comprehensive knowledge use.

\section{Enrich practical form.}

In computer teaching plan ensure that the practice time account more than $30 \%$ of the total class hours and enable students to master new knowledge through the practice project training, improve computer application ability. In addition to the classroom teaching practice, higher vocational colleges should also strengthen students' ability training through extracurricular practice, such as the carry out innovation engineering project design, extra-curricular interest groups, IT technology competition, etc. so that let the students in extracurricular practice consolidate the knowledge and skills for database design, web design, program design, computer installation, etc. At the same time, higher vocational colleges should also encourage students to participate in the provincial design competition. If the students obtain the corresponding honorary certificates, they enhance the students' employment competitive.

\section{Improve the quality of the teachers}

Higher vocational computer education need a high quality teacher troop as the powerful guarantee to make computer education get out of the predicament and realize the goal of computer education. First of all, to optimize the structure of teachers' professional in higher vocational college, actively introduce computer teaching personals with advanced degrees and ensure that the computer teacher education at least have bachelor degree or above. Because of the higher vocational college is the main land to cultivate skilled persons, so the teachers should not only pay attention to the cultivation of computer professionals, and also to other majors' students' informatization level ascension to adapt to high demand for talent information under the information age development.

Second, make double-professionally-titled teachers. Higher vocational teachers should not only master the comprehensive computer professional knowledge, but also have strong ability of practical application ability. Has the rich experience of work in the enterprises and the capability of cultivation of students' comprehensive skills. Again, the computer teachers should constantly working on their own knowledge as well as learning new computer technology to make sure students understand and master the latest computer knowledge. Higher vocational colleges should encourage teachers' further education and provide teachers with the opportunity to study, to improve teachers' comprehensive quality. Teachers in the teaching become leading type, technology-based and demonstration type teachers who continuously improve their teaching ability and attach importance to students' problem solving ability, hands-on ability and the training of innovative applications, to promote vocational college computer professionals have a sustainable development.

\section{Conclusion}

In the new period, higher vocational colleges should intensify computer education reform, thoroughly improve the current situation of the poor teaching quality to ensure the realization of the talents training goal of higher vocational computer education. Colleges and universities from the optimization of curriculum system, improving teaching methods, strengthening practice teaching, improve the quality of teachers, etc. to build to education teaching system which conform to the requirements of cultivating the high quality applied talents, and constantly improve the effect of computer education to make students master the computer comprehensive knowledge and computer application skills to strengthen employment competitiveness.

\section{References}

[1] Jiang Puyang: The combination of higher vocational education and double certification education-higher vocational computer education reform exploration. New curriculum (I).2013(11) 
[2] Cheng Zhi: The Thinking on Reform of Higher Vocational Computer Course Teaching. Course Education Research. 2013 (10).

[3] Liao Hongjian: Higher Vocational College Computer Basic Education Course Teaching Exploration. Computer Knowledge and Technology. 2012 (4).

[4] Liu Jing: Suo Hongjun. The Higher Vocational College Public Computer Education Current Situation, Value Engineering. 2011 (7).

[5] Yu Hui: Higher Vocational Computer Case Teaching Process and Strategy Research. Modern Commercial Industry. 2008 (12).

[6] Yan Lixin: "Project-oriented" Teaching Method Application in Higher Vocational Computer Teaching. Education and Profession. 2012 (12).

[7] Deng Shigen: Try to Talk about Higher Vocational Computer Teaching Positioning, Age Education (education teaching). 2012 (2). 